\title{
Cement Production and Sustainable Rural Farming Livelihood in Nigeria: Striking a Sensible Balance Through Environmental Legislation and Enforcement
}

\author{
By Okojie, L. O ${ }^{1}$.
}

\begin{abstract}
This paper undertook the damage valuation of cement production induced air pollution on rural farming livelihood, assessed the impact on farmers' profitability as well as investigating the corporate social responsibility investment of the cement companies in the producing host communities in Nigeria. It then examined how legislation and enforcement can be made to strike a sensible balance between the environmental damage enabled by cement pollution and ensuring a sustainable farming livelihood. A two stage simple random sampling procedure was adopted for the paper to select a total of 120 respondents in the target and control areas. Data were analyzed using descriptive statistics, Dichotomous-Choice Contingent Valuation Method (DC-CVM) that terminated into the logit model and the budgetary analysis. The total Willingness-To-Pay (WTP)/annum to avert the negative externalities on the host communities' farming livelihood was $\$ 3.21$ billion. The profitability in farming in the target cement producing area with respect to the net farm income and the rate of return to capital investment were lower in the target as compared to the control area. The Corporate Social Responsibility (CSR) investments of the cement producing companies were small compared to the profits realized by them. The proportions of the CSR investments with respect to the company's profits were between $0.4 \%$ and $1.6 \%$ for the five years considered in the paper. Efforts have been made by the government to enact laws, regulations and standards to ensure environmentally sound and sustainable environment though the institution initially put in place to implement them was not given legal powers of enforcement. Things are however changing with the establishment of another with such powers. It is only by such proper implementation, a sensible balance can be struck between uncontrolled cement dust pollution associated with excess profits to the cement producers and sustainable farming livelihood guarantee with enhanced corporate social responsibility ensured to the host communities.
\end{abstract}

Keywords: Environmental damage, pollution, valuation, corporate social responsibility, livelihood, legislation, enforcement.

\section{Introduction:}

A two stage simple random sampling procedure was adopted for the paper. The first consisted of randomly selecting five wards each from ten in the target and twelve in the control areas. Cement is the most common and widely used building material in the 
world and its by-product concentrate is the second most consumed substance universally after water. Unlike in areas where close substitutes like brick are used in the construction industry, cement constitutes over 95 percent inputs of basic infrastructural developments in Nigeria. Many analysts have pointed out that after the petroleum industry in the country, the cement industry is the most controversial and most politicized because of the policy somersaults that relate to the proportional allocation to importation and domestic production.

The air pollution encountered in cement production has however been a source of major concern in the sustainability of rural livelihoods which focuses mainly on food crop production. The rural people have been so impacted on in the areas of health, soils, water, agricultural production and productivity. With respect to health, morbidity and mortality have been recorded. These have been well documented (World Development Indicator, 2004; Quah and Boon, 2002; Cropper et al., 1997; Ostro et al; 1996; Dockery et al; 1993). Dockery et al. (1993) shows that the risk of early death in areas with high concentration of particulate air pollution is $26 \%$ higher in comparism to where it is lower. This is supported by Schwartz (1996) and Ostro et al. (1996). The latter in a study of Santiago, Chile revealed that death from respiratory and cardiovascular diseases were linked to exposure of small particles concentration of air pollution. Such results are reinforced by recent studies in the air pollution epidemiological literature (Quah and Boon, 2002). Bronchitis and its symptoms are prevalent in people with greater exposure to suspended particulates. Emission by the cement industry to the air that includes materials such as kiln, dioxin, cement dust and particulates are harmful to man, animals and plants. Exposure to dioxin for instance affects the immune system, fertility and the unborn child. Infection of the lung through exposure to cement dust causes asthma, cancer and various respiratory diseases. Cough, sore throat and eye irritation also result. The people that ought to be active in the farms are so affected by such emissions from the incinerators, trucks and quarry sites of the cement concerns. This has a very grave implication for sustainable livelihood in areas with cement dust pollution. A healthy population stands the higher chance of engaging in sustainable livelihood activities. The channelization of slurry water and kiln into the rivers also occur in the areas where these cement companies operate and so affect environmental sustainability as kiln contains mercury. When this enters the aquatic system, it accumulates in the food chain causing harmful effects or death on consumption.

With respect to cement dust impact on agricultural food crops, Ade-Ademiliaa and Abalola (2008) noted that there was no significant effect on the germination of the vegetable - Lagos Spinach. A significant reduction in shoot length and leaf area were however prevalent. This they attributed to the toxic effect of aluminum that inhibits root absorption and plant growth. The dry weights of polluted plants were found to be significantly lower than those of the control plants. The reduced vegetative size they also attributed to reduction in photosynthesis as the cement dust prevented the leaves from capturing sufficient light energy as compared to the control plant. The dust they also claimed interrupted gaseous exchange through stomata clogging, reduced transpiration and inhibition of intracellular processes. The epidermal cells and stomata of polluted leaves they observed were equally altered by the cement dust. They also asserted that a reduction of vitamin $\mathrm{A}_{2}, \mathrm{~B}_{2}$ and $\mathrm{C}$ and an increase of concentration of heavy metals $-\mathrm{Fe}$, $\mathrm{Zn}, \mathrm{Cu}, \mathrm{Mg}, \mathrm{Al}, \mathrm{Si}$ and $\mathrm{S}$ occurred in plant leaves and stems. These definitely do not 
create sustainability in the farming livelihood of cement producing area residents as there is the extreme likelihood they will cause harm in consumption.

In spite of all these negative externalities of the cement production companies is the very poor performance in their Corporate Social Responsibility (CSR). CSR is the responsibility of an organization for the impacts of its decisions and activities on society and the environment through transparent and ethical behavior that is consistent with sustainable development and the welfare of society. It is understood to be the way firms integrate societal, environmental and economic concerns into their values, culture, decision making, strategy and operations in a transparent and accountable manner to establish better practices within the firm, create wealth and improve societies. CSR typically includes "beyond law" commitments and activities pertaining among many others health safety, environmental stewardship and sustainable development. In addition are industrial relations and community involvement, development and investment. The cement industry in Nigeria is seriously failing in these aspects and there is the need to enact environmental legislations and enforce compliance especially with the functions they are expected to perform "beyond law" or beyond legislation as enumerated earlier.

It is in this instance, this paper aims to describe the socio-economic characteristics of the farmers, identify the ecosystem functions impacted negatively on by cement production and undertake the valuation of the environmental damage caused. In addition is to assess the impact of the cement production on the profit realized by the farmers, compare it to the annual profit declared by the cement companies and weigh these annual profits against their corresponding CSR. This will justify the need to review or enact new environmental legislation to strike a sensible balance between cement production with its attendant externalities and enhancement of sustainable farming livelihood in the area of study.

\section{Methodology:}

\subsection{Study Area:}

The study area is Ogun State where the two biggest cement factories in Nigeria - Dangote and WAPCO Lafarge that jointly produce 95 percent of Nigeria's total output operate in. The latter at Ewekoro, the major producer until the recent advent of the former with long enough data was taken as the major focus. The control area was taken as Obafemi-Owode LGA. The former has its headquarters at Itori $\left(6^{0} 56^{\prime} \mathrm{N}\right.$ and $\left.3^{0} 13^{\prime} \mathrm{E}\right)$, an area of $549 \mathrm{~km}^{2}$ and a population of 55,039 (NPC, 2006). The latter has the headquarters at Owode $\left(6^{0} 57^{\prime} \mathrm{N}\right.$ and $\left.3^{0} 30^{\prime} \mathrm{E}\right)$, an area of $1,410 \mathrm{~km}^{2}$ and population of 228,851 . The peoples' main source of livelihood is farming. Limestone, the major raw material for cement production abounds in Ewekoro LGA.

\subsection{Data Sources and Collection:}

The data for the analysis were collected from a cross sectional survey using structured questionnaire as interview guide. With respect to the cement dust damage assessment on rural farming livelihood in the target area, a pre-test open-ended Dichotomous-Choice Contingent Valuation Method (DC-CVM) survey was carried out from which the unique bids and their optimal sample allocations were worked out. This was then used in the actual DC-CVM survey. Primary data relating to determination of 
farm incomes in the target and control areas were collected in cross sectional surveys in the respective areas while secondary data from the companies' records were used in assessing their profits and corporate social responsibilities.

\subsection{Sampling Techniques:}

Random selections of ten farmers each were undertaken in each of the wards to make a total of 120 respondents in the two study areas.

\subsection{Analytical Procedures:}

The analyses involved descriptive analysis that involved the use of tables, frequency, mean, and percentages to describe the socio-economic characteristics of the respondents. The DC-CVM that terminated into the logit model was equally used to derive the coefficients of the covariates through the maximum likelihood estimation approach. These coefficients were then used to do the damage assessment of the cement dust pollution on the rural farms for food crops production. This is following Hanemann (1984) and Cooper and Loomis (1992) as replicated by Turcin and Giraud (2001) and Okojie (2007). This assessment as conceptualized through the Willingness To Pay (WTP) from the farmers perspective is as derived from the following models:

Where:

$$
L_{i}=\frac{1}{\left[1+e^{-(\alpha+\beta x i)}\right]}
$$

$L_{i}=$ Respondent acceptance probability to the bid offered.

$\beta_{\mathrm{i}}=$ Vector representing the coefficients of all covariates.

$\mathrm{X}_{\mathrm{i}}=$ Vector representing all covariates

The covariates are as follows:

$\mathrm{X}_{1}=$ Bid, $\mathrm{X}_{2}=\mathrm{Sex}, \mathrm{X}_{3}=$ Age, $\mathrm{X}_{4}=$ Household size, $\mathrm{X}_{5}=$ Level of education, $\mathrm{X}_{6}=$ Income,

$\mathrm{X}_{7}=$ Disease dummy $($ Yes $=1 ; \mathrm{No}=0) ; \mathrm{X}_{8}=$ Support for intergenerational equity $($ Yes $=1$; No $=0), X_{9}=$ Immigrant dummy $($ Yes $=1$; No $=0)$

The Cooper and Loomis (1992) procedure for the determination of mean WTP is as follows:

$\mathrm{P}^{-}=1 /|\beta| * \ln \left(1+\exp ^{\mathrm{a}}\right)$

Where:

$$
\begin{aligned}
& a=\text { Intercept } \\
& \beta=\text { Coefficient of bid } \\
& P=\text { Restricted mean WTP. }
\end{aligned}
$$

The budgetary method was used to derive the profits realizable by farmers with and without cement air pollution. The model is as specified:

$$
\begin{gathered}
\text { GM = TR-TVC.. } \\
\text { NFI = GM -TFC.. }
\end{gathered}
$$

Where:

$\mathrm{GM}=$ Gross margin

$\mathrm{TR}=$ Total revenue

TVC $=$ Total variable cost 
TFC $=$ Total fixed cost

NFI $=$ Net farm income

Analysis of the annual reports of the adopted cement factories provided the annual profits and the equivalent corporate social responsibilities. Existing environmental laws or policies in place to mitigate cement dust emission where available were assessed to check for compliance. Corporate social responsibility in place and policies guiding their implementations were equally assessed. Urgent call for new environmental laws and enforcement were therefore made where inadequacies existed for sustainable development in the cement production areas. In such a way, it was expected more ecofriendly technologies employing cleaner development mechanisms could be enforced on the cement companies that would enhance sustainable development.

\section{Results And Discussion}

\subsection{Socio-Economic Characteristics}

The farmers in the target and controlled areas were mostly of the male gender with $78.5 \%$ and $78 \%$ and mean age of 55years and 50 years in that order. They were mostly married (above $89 \%$ in both areas) and the household sizes were quite large in both cases ranging averagely from 3-6 persons. The literacy level in the target area $(54.4 \%)$ was lower as compared to the control area that had $75.6 \%$. This implies the greater tendency for many respondents in cement producing areas to get involved in the menial job aspect in the cement industry available in their location. This may also create a lower awareness of the danger of cement dust air pollution in the target area and so the tendencies to value lower the damage impact. The income of respondents in the target area is higher than that in the control area. This is understandable as the opportunity for the farmers to avail themselves in other occupations especially as related to different operations in the cement industry abound here. Majority of the respondents in both areas were indigenes and on ethnocentric grounds indigenes in cement producing area are more likely to avert damage and seek for greater corporate social responsibility.

\subsection{Damage Assessment of Cement Dust Pollution}

The cement dust air pollution damage assessment was done with the dichotomous-choice contingent valuation method through the willingness to pay concept. This terminated into the logit model and the maximum likelihood estimation of the resultant logit model is shown in Table 1. This provided the necessary coefficients with which the damage assessment was carried out. The mean WTP in this respect was 405: = per respondent per month. On annual basis, this resulted to $\$ 4,860$ : = per respondent. Aggregating this for 55,039 people in the study area gives a total WTP of $\$ 22,290,795$ / month and an annual total WTP of $\$ 3,209,874,480$ (i.e. 3.21 billion). This in effect means that the total damage value resulting from cement dust air pollution for the immediate surrounding cement producing areas is 3.21 billion/annum. 
Table 1: The Maximum Likelihood Estimations of Responses to WTP Questions

\begin{tabular}{lllll}
\hline WTP & Coefficient & Standard error & $\mathbf{Z}$ & $\mathbf{P}>/ \mathbf{Z} /$ \\
\hline Bid & -.0037604 & .0012752 & -2.95 & $0.003^{* * *}$ \\
Sex (dummy) & 1.044841 & .7291795 & 1.43 & 0.152 \\
Age & .0308451 & .0355993 & 0.87 & 0.386 \\
Household Size & -.2120524 & .2369109 & -0.90 & 0.371 \\
Education & .2353864 & .068448 & 3.44 & $0.001^{* * *}$ \\
Income & -4.32 & .0000124 & -0.35 & 0.727 \\
Disease Condition (Dummy) & -.3590944 & .6814588 & -0.53 & 0.598 \\
Constant & 1.280248 & 1.82333 & 0.70 & 0.483 \\
\hline Source: Computed from Fite & & & &
\end{tabular}

Source: Computed from Field Survey Data, 2012

The total fixed cost for the target area was $\$ 23,553.75$ and $\$ 35,380$ in the control area (Table 2). The total variable cost was 44, 993.75 and $\$ 311.25$ per average farm size in the target and control area respectively. These amount to total cost of production of $\$ 68,547.50$ and $\$ 128,691.25$ per average farm sizes respectively for the target area and the control area. This disparity is understandable from the difference in the size of the farm holdings which is bigger in the case of the control areas. The type of crop grown in the target area which was more of cassava in mono cropping system as compared to the more costly root crops grown in the control area could have led to the relative reduced total cost in the target area. The total revenue/average farm size in the target area was $\$ 134,054.51$ and in the control area, it was $\$ 262,631.94$. This translates to the net farm income per hectare of $\$ 65,507.01$ in the target area and $\$ 133,940.69$ in the control area. The earning of the control areas is quite higher than that of the target cement production dust polluted area. The productivity of the land in the target area is more likely lower as a result of the negative externalities of the cement production dust pollution on the soil, water quality and crops photosynthesis. The rate of return to capital invested in the control area is $104 \%$, while it is $96 \%$ in the target cement polluted area. This signifies higher profitability in the control area as compared to the target area, further justifying the negative externalities of the cement production dust pollution on agricultural crops in the area.

Table 2: Profitability Analysis in Food Crop Production in Cement Production and Control Areas.

\begin{tabular}{|c|c|c|}
\hline Cost/Revenue Items & Cement Producing Area & Control Area \\
\hline Total Fixed Cost ( & $23,553.75$ & 35,380 \\
\hline Total Variable Cost ( & $44,993.75$ & $93,311.25$ \\
\hline Total Cost ( & $68,547.50$ & 472737.50 \\
\hline Average Farm Size (Ha) & 1.72 & 1.80 \\
\hline Total Revenue/AF Size ( & $134,054.51$ & $262,631.94$ \\
\hline Gross Margin/AF Size ( & $89,060.76$ & $169,320.69$ \\
\hline Net Farm Income/Hectare ( & $65,507.01$ & $133,940.69$ \\
\hline Rate of Return to Investment ( $\%)$ & 95.56 & 104 \\
\hline
\end{tabular}

Source: Computed From Field Survey Data, 2012. 


\subsection{Annual Profits and Corporate Social Responsibility of Cement Producing Companies}

The profits and the CSR investments of the major cement company in the study area in the periods of 2007 - 2011 are as shown in Table 3. The CSR investment increased as the year increased despite the fluctuations in the profits made by the cement companies. The percentage of the CSR investment to the profit of the cement company indicates that the investment in the target area was minimal compared to the profit realized. In the year $2007,0.4 \%$ of the profit made that year represented the investment in CSR. These were $0.6 \%, 1.4 \%, 1.6 \%$ and $1.0 \%$ in the years 2008 to 2011 in that order. The implication is that the CSR investments made for the five years period $(2007-2011)$ by the cement companies were very minimal as compared to the huge profits that did not internalize the cost of the environmental damage and has resulted in the non sustainability of the farming livelihood in the study area. This equally shows that there is no effective legislation is in place and even if it were no serious efforts are made in the direction of enforcement.

Table 3: Proportion of Corporate Social Responsibility on Profit of Cement Company

\begin{tabular}{llll}
\hline Year & Profit (N) & CSR(N) & $\%$ \\
\hline 2007 & $10,678,652,000$ & $40,000,000$ & 0.4 \\
2008 & $11,252,030,000$ & $63,000,000$ & 0.6 \\
2009 & $5,055,398,000$ & $73,000,000$ & 1.4 \\
2010 & $4,881,363,000$ & $77,000,000$ & 1.6 \\
2011 & $8,509,347,000$ & $88,000,000$ & 1.0
\end{tabular}

Source: Computed From Annual Reports of Cement Companies in Study Area

The CSR consisted mainly of investment in health, infrastructure and provision of agricultural aid. In addition are youth empowerment, education, shelter and security.

3.4 Environmental Legislation and Enforcement in Nigeria

The viability or otherwise of the agricultural sector is crucial to the growth and development of a nation. The agriculture sector strongly impacts food security, industrialization efforts, quality of life, economic growth, political stability and, to a certain extent, a nation's position in international relations and trade. The sustainability of this important sector should, therefore, be of paramount importance. Consequently, it is essential to establish a balance between efficient farming livelihood and environmental degradation. It is in this line, Nigeria took a giant leap by becoming an environmentally conscious nation in 1987. This followed the incidence of the dumping of toxic waste in Koko village, in Delta State. The country was before this incident, ill-equipped to manage such environmental crisis, as there were no institutional capacity and legislations to address such matters. The promulgation of the Harmful Waste Decree 42 of 1988, which facilitated the establishment of the Federal Environmental Protection Agency (FEPA) through Decree 58 of 1988 and 59 (amended) of 1992 came into effect.

FEPA was charged with the overall responsibility for environmental management and protection. In the wisdom of Government, FEPA and other relevant Departments in other Ministries were merged to form the Federal Ministry of Environment in 1999, but without an appropriate enabling law on enforcement issues. This situation, however, 
created a vacuum in the effective enforcement of environmental laws, standards and regulations in the country and this necessitated the establishment of the National Environmental Standards and Regulations Enforcement Agency (NESREA) in line with section 20 of the 1999 Constitution of the Federal Republic of Nigeria as a parastatal of the Federal Ministry of Environment, Housing and Urban Development. Nigeria has since been committed to a national environmental policy that is expected to ensure sustainable development based on proper management of the environment. This requires that a number of complementary policies, strategies and management approaches are put in place to ensure that environmental concerns are integrated into major economic decision- making process and environmental remediation costs are built into major development projects. In addition are to ensure that economic instruments are employed in the management of natural resources, environmentally friendly technologies are applied and environmental impact assessments are mandatorily carried out before any major development project is embarked on. The policy emphasizes "Pollution Prevention Pays Principle $(3 \mathrm{p}+)$ " which encourages industry to invest positively to prevent pollution and the "polluter pays principle (PPP)" which recommends that the polluter should bear the cost of preventing and controlling pollution. It also in addition emphasizes the "user pays principle (UPP)", in which the cost of a resource to a user must include all the environmental costs associated with its extraction, transformation and use (including the costs of alternative or future uses forgone)

It is expected for this policy to succeed, it must be built on the precautionary principle which holds that where there are threats of serious or irreversible damage, the lack of full scientific knowledge shall not be used as a reason for postponing cost-effective means to prevent environmental degradation. The principles of intergenerational equity and intragenerational equity are equally emphasized in the policy. The former requires that the needs of the present generation must be met without compromising the ability of future generations to meet their own needs while the latter requires that different groups of people within the country and within the present generation have the right to benefit equally from the exploitation of resources.

The role of legislation in inducing responsible attitudes and behaviors towards the environment cannot be overlooked. Legislation serves as an effective instrument for environmental protection, planning, pollution, prevention and control. Legislation on the environment in Nigeria emanates from the Constitution of the Federal Republic of Nigeria (1999), National Environmental Standards and Regulations Enforcement Agency (NESREA) Act, Environmental Impact Assessment Act, the Land Use Act, Harmful Waste (Special Criminal Provisions) Act and Hydrocarbon Oil Refineries Act. Among many others are Associated Gas re-injection Act, The Endangered Species Act, Sea Fisheries Act, Nuclear Safety and Radiation Protection Act, Nigerian Mining Corporation Act, River Basins Development Authority Act, Pest Control of Production (special powers) Act, Factories Act and the Water Resources Act.

The constitution, as the national legal order, recognizes the importance of improving and protecting the environment and makes provision for it. The relevant sections are Section 20 which makes it an objective of the Nigerian State to improve and protect the air, land, water, forest and wildlife of Nigeria. In addition is Section 12 which establishes, though impliedly, that international treaties (including environmental treaties) ratified by the National Assembly should be implemented as law in Nigeria. Sections 33 and 34 that 
guarantee fundamental human rights to life and human dignity respectively have also been argued to be linked to the need for a healthy and safe environment to give these rights effect.

The National Environmental Standards and Regulation Enforcement Agency (NESREA) Act of 2007 replaced the Federal Environmental Protection Agency (FEPA) Act. It is the embodiment of laws and regulations focused on the protection and sustainable development of the environment and its natural resources. Section 7 of it provides authority to ensure compliance with environmental laws, local and international, on environmental sanitation and pollution prevention and control through monetary and regulatory measures. Its Section $8(1)(K)$ empowers the Agency to make and review regulations on air and water quality, effluent limitations, control of harmful substances and other forms of environmental pollution and sanitation. Section 27 prohibits, without lawful authority, the discharge of hazardous substances into the environment. This offence is punishable under this section, with a fine not exceeding, $\mathrm{N} 1,000,000$ (One Million Naira) and an imprisonment term of 5 years. In the case of a company, there is an additional fine of $\mathrm{N} 50,000$, for every day the offence persists. The National Effluent Limitation Regulations in Section 1 (1) requires industry facilities to have anti-pollution equipment for the treatment of effluent. The Section 3 (2) requires a submission to the agency of a composition of the industry's treated effluents while the National Environment Protection (Pollution Abatement in Industries and Facilities producing Waste) Regulations (1991) in its Section 1 prohibits the release of hazardous substances into the air, land or water of Nigeria beyond approved limits set by the Agency. The Section 4 and 5 of this document requires the report of discharge if it occurs and to submit a comprehensive list of chemicals used for production to the Agency. The foregoing discussion and many others on the ground show beyond reasonable doubt that legislation to control environmental hazards such as cement induced air pollution exist in Nigeria but enforcement has been lacking. The implications have been the morbidity and mortality of people in the cement producing host communities earlier discussed and the negative impacts on farming livelihood through the negative externalities that manifest in soil, water, farm crops and other environmental facilities.

\section{Conclusion}

The respondents in farming livelihood in the target and control areas were mainly of the male gender with the mean ages of 50 and 55 years in that order and they were mostly married. The large household sizes ensured family labor availability to farming cores. The literacy level was very lower (54.4\%) as compared to the control area $(75.6 \%)$. The implication is that there was quite a sacrifice of education for the readily available menial labor in the cement factories in the target area.

The damage assessment in the target area through the WTP concept was approximately N3.21 billion on annual basis. This could have accounted for the lower profit (N65,507.01/ha) and Rate of Return To Investment (RRTI) of $95.56 \%$ realized through the farming livelihood in the target cement producing area as compared to the control area with the profit of N133,940.69/ha and RRTI of 104\%. The productivity of the land in the target area was more likely lower because of the negative externality of cement dust pollution and other processes associated with its production. 
The CSR investments in the target area of cement production was way out of proportion as compared to the huge profits declared on yearly basis by the cement companies in the target area. The CSR was only N40 million for the first year considered in the study when the cement company profit was N10.7 billion, a mere $0.4 \%$ proportion of the profit. In general, the CSR could be said to have increased with advancement in years for the five years period considered but the individual proportions on the equivalent cement factories' declared profits were still insignificant as they only rose from $0.6 \%$ to $1.6 \%$. This presents a case where the cement companies are playing the "winner takes all" with no much consideration to ploughing back to the host communities from where much of the profits were derived. Instead their production methods contribute to poor farm yields and health of the people in the host communities. This is where government intervention is needed to be able to strike a sensible balance between the cement companies' induced air pollution combined with the zeal to maximize profit and the host communities wish to have sustainable farming livelihood in addition to enhanced CSR. Environmental legislation and enforcement by the government are necessary to ensure this.

In line with the above, protecting the environment through legislation started in earnest in Nigeria with the dumping of toxic waste in Koko, Delta State by some foreign concerns in 1988. The "Harmful Waste" Decree 58 of 1988 facilitated the establishment of FEPA. There was a problem as FEPA was created without an appropriate enabling law on enforcement. This created a vacuum in effective enforcement of environmental laws, regulations and standards. For this reason NESREA was established in line with Section 20 of the 1999 Constitution of the Federal Republic of Nigeria as a parastatal of the now Federal Ministry of Environment. The NESREA Act of 2007 replaced the FEPA Act. The environmental laws to take care of pollution and other environmental hazards can therefore be said to be in place. The problem has however been of aggressive enforcement. The NESREA equally owns up to this by recently calling for a stakeholders meeting for awareness and sensitization almost after eight years of establishment (The Tide Newspaper, 2014).

There is therefore the urgent need for government intervention through NESREA to ensure that all the environmental legislations especially the one that relates to cement dust production and air pollution in the country is seriously enforced. The cement companies must be made to know that the environmental cost emanating from their negative externality supposed to be internalized within their operation cost. This implies that the average environmental damage of N3.21 billion ought to be inputted into their operational cost and ceded to the government to ameliorate damages arising in the target cement areas before the consideration of their CSR to the host communities. This if done will go a long way to the restoration of profits lost through farming livelihood and medical bills incurred as a result of ill health resulting from cement dust pollution. It will also go a long way to off-setting the monetary account of other environmental degradations resulting from cement production. A cleaner development mechanism in production will be sought by affected cement factories to reduce the monetized "polluter pays principle" bill accruing to them. It is only when these are implemented, we can be said to be going a long way in striking a sensible balance between the benefits reaped from cement production and the amelioration of environmental costs in the form of negative externality inflicted on farming livelihood embarked on by the cement producing host communities. 


\section{References}

Ade-Ademilua, O.E. and Abalola, D.A (2008). The effect of cement dust pollution on Celosia argentea (Lagos spinach) plant. Journal of environmental Science and Technology; 1(2): 47-55 Turcin and Giraud, (2001). "Contingent Valuation Willingness to Pay with Respect to Geographically Nested Samples: Case Study of Alaskan Steller Sea Lion", Paper Presented at the W-133 Annual Meeting. Miami FL: United States, Department of Agriculture, February.

Cooper, J.C (1993). "Optimal bid selection for dichotomous choice contingent valuation surveys". Journal of Environmental Economics and Management 24, 25-40.

Cropper, M.L., Nathalie B. Simon, Anna Alberini, Seema Arora, and P.K. Sharma, (1997),

"The Health Benefits of Air Pollution Control in Delhi," American Journal of Agricultural Economics, 79 (5): 1625-29.

Dockery D.W, Speizer FE, Stram DO, Ware JH, Spengler JD (1989). "Effects of inhalable particles on respiratory health of children". Am Rev Respir Dis (139):587-594.

Dockery D.W., CA Pope III, X Xu, JD Spengler, JH Ware, ME Fay, BG Ferris and FE Speizer

(1993). "An association between air pollution and mortality in six US cities". New England J of Medicine, vol.329, p.1753-1759.

Hanemann, M. (1984). "Welfare Evaluation in Contingent Valuation Experiments with Discrete

Responses". American Journal of Agricultural Economics, 66:332-341.

National Environmental Standards and Regulations Enforcement Agency

http://www.nesrea.gov.ng (accessed 20th March, 2014).

Okojie, L. O. 2007. Socio-Economic and Environmental Attitudinal Determinants of Rainforest Protection: A Logit Model Analysis. ASSET An International Journal Series C 2(1):204-218.

Ostro, B. (1995). Fine Particulate Air Pollution and Mortality in Two Southern California Counties, Environmental research, 70: 98-104.

Ostro, B., Sanchez, J. M., Aranda, C., and G.S. Eskeland (1996). "Air Pollution and Mortality:

Results from a study of Santiago, Chile". Journal of Exposure Analysis and Environmental Epidemiology, 6 (1): 97-114.

Quah, E. and T.L. Boon (2002). "The Economic Cost of Particulate Air Pollution on Health in

Singapore," Journal of Asian Economics, (14): 73-90.

Schwartz, J. (1996). "Air Pollution and Child Mortality: A Review and Meta analysis",

Environmental Research, (64): 36-52.

The Tide Newspaper (2014). Enforcing Environmental Regulations In Nigeria - 2. Issue of Wednesday 02 April.

World Development Indicators (2004), World Bank, Washington, DC, USA.

Working definition, ISO 26000 Working Group on Social Responsibility, Sydney, February

2007Source:http://strategis.ic.gc.ca/epic/site/csrrse.nsf/vwapj/stakeholder.txt/\$FILE/stakeholder.txt (accessed 20th March, 2014). 
